\title{
The Poetics of Singularity
}


The Frontiers of Theory

Series Editor: Martin McQuillan

The Poetics of Singularity: The Counter-Culturalist Turn in Heidegger, Derrida, Blanchot and the later Gadamer

Timothy Clark

Forthcoming:

Scandalous Knowledge: Science, Truth, and the Human Barbara Herrnstein Smith

Dreams I Tell You

Hélène Cixous

Genius, Genealogies, Genres and the Genie Jacques Derrida 


\section{The Poetics of Singularity}

The Counter-Culturalist Turn in Heidegger, Derrida, Blanchot and the later Gadamer

Timothy Clark 
(C) Timothy Clark, 2005

Transferred to Digital Print 2010

Edinburgh University Press Ltd

22 George Square, Edinburgh

Typeset in Adobe Sabon

by Servis Filmsetting Ltd, Manchester

Printed and bound in Great Britain by

CPI Antony Rowe, Chippenham and Eastbourne

A CIP record for this book is available from the British Library

ISBN 0748619291 (hardback)

The right of Timothy Clark

to be identified as author of this work

has been asserted in accordance with

the Copyright, Designs and Patents Act 1988. 